\title{
Effectiveness of Composting Road-Killed Deer In New York State
}

\author{
M. Schwarz ${ }^{1}$, J. Bonhotal ${ }^{1}{ }^{*}$, E. Harrison, W. Brinton ${ }^{2}$ and P. Storms ${ }^{2}$ \\ 1. Cornell Waste Management Institute, Cornell University, Ithaca, New York \\ 2. Woods End Laboratories, Inc., Mt. Vernon, Maine \\ *E-mail contact: jb29@cornell.edu
}

\begin{abstract}
Composting of deer carcasses was effective in reducing pathogen levels, decomposing the carcasses and producing a useable end product after 12 months. The composting process used in this project involved enveloping the carcasses of road-killed deer in woodchips and allowing those piles with natural air circulation to sit undisturbed. Temperatures were measured and samples from the piles were analyzed periodically for pathogens and for compost parameters. While significant pathogen reduction occurred in several months, it took 12 months for all of the measured pathogens to decline to low levels in all of the 6 piles studied. Samples taken at other sites in New York State that have been composting road-killed deer for over a year also had low pathogen content. We thus suggest a composting duration of 12 months before use. In the interest of being cautious, we also recommend that the end product be used in low public contact settings such as highway rightsof-way.
\end{abstract}

\section{Introduction}

The effectiveness of inactivating pathogens through composting is generally assessed by monitoring the reduction in fecal coliform bacteria and Salmonella. These are the indicator organisms that the USEPA requires for evaluation of the hygienic quality of sewage sludges. Mammalian intestines are full of fecal coliform, mostly E. coli, but there is particular concern about the pathogenic strain O157. Most of the literature agrees that Salmonella spp. and E. coli O157:H7 are absent from deer (Koronkiewicz, et al. 2004, Lillehaug, et al. 2005). The apparent inability of deer to act as carriers [of Salmonella] may be because they lack a gall bladder, a site where Salmonella spp. can colonize (Henderson and Hemmingsen 1983). Branham, et al. (2005) found Salmonella spp. in 7.69\% of samples collected from white-tailed deer and other livestock in Texas, but E. coli $\mathrm{O} 157$ was found only in cattle, sheep and water, and only during the well-documented seasonal shedding pattern of these bacteria. The low overall prevalence of these organisms in wild deer suggests that they are not a major reservoir of either bacterium.

Therefore evaluation of the effectiveness of static pile composting to inactivate pathogens in road-killed deer carcasses required identification of the pathogens that might be present and analysis of their sensitivity to inactivation by heating. The prevalence of Clostridium perfringens, Listeria, Campylobacter and Yersinia in wildlife has all been studied. Clostridia that survive at low temperatures were isolated from hides, feces and tonsils of deer slaughter stock, making handling of these animals important (Broda, et al. 2002). Clostridium botulinum may be found in the intestinal tract and perhaps other organs of healthy animals. It does no harm there, but, if the animals die, it may multiply and produce toxins in their carcasses. In a study in Poland, it was confirmed that red deer and roe deer were carriers of Listeria and Campylobacter (Koronkiewicz, et al. 2004). Several studies indicate that wild ruminants are a major reservoir of Yersinia (Shayegani 1983, Henderson 1984, Pagano, et al. 1985).

There are conflicting reports among the researchers as to whether or not deer are primary carriers of Leptospira species. Shotts, et al. 1958, Reily, et al. 1962 and Roth, et al. 1964, all indicated that deer can be carriers of leptospires. Others report that deer are not a primary reservoir (Fleming and Nusbaum 1979, Ingebrigsten 1986). White-tailed deer shed Giardia spp. cysts and Cryptosporidium spp. oocysts in the environment and must be considered potential sources of contamination. However, the incidence decreases in animals greater than six months of age (Rickard, et al. 1999).

Tuberculosis is primarily a respiratory disease and transmission of infection within and between species is mainly by the airborne route. Mycobacterium bovis, the cause of bovine-type tuberculosis, has an exceptionally wide host range. Susceptible species include cattle, humans, non-human primates, goats, cats, dogs, pigs, buffalo, badgers, possums, deer and bison ( $\mathrm{O}^{\prime}$ Reilly and Daborn 1995). Survival of M. bovis outside its host is dependent on ambient environmental conditions: maxi- 
mum survival occurs in cold, damp conditions, while exposure to direct sunlight under dry conditions lessens its survival. Estimates of distribution of bovine TB in free-ranging white-tailed deer suggest prevalence of less than $5 \%$. The risk to human health is greater for those in close contact with live deer or handling infected carcasses (Clifton-Hadley 2001).

The literature reviewed here suggests that the pathogens expected to be found in white-tailed deer and other wildlife is as follows:

- Salmonella - very little to none

- E. coli and fecal coliforms - conflicting reports on $E$. coli $\mathrm{O} 157: \mathrm{H7}$, but other coliform are present and can be a source of human infection

- Clostridium - present, especially in the gut and multiply when the animal dies

- Listeria - present, but probably not an important source

- Campylobacter - very little to none

- Yersinia - wild ruminants may be important carriers

- Leptospira - conflicting reports

- Cryptosporidia and Giardia - also conflicting reports, but more likely in younger animals

- Mycobacteria - present, but probably in less than $5 \%$ of the population

The effectiveness of inactivating pathogens through composting is generally assessed by monitoring the reduction in indicator organisms. Salmonel$l a$ and fecal coliform are the usual indicator organisms. It is widely recognized that the sensitivity of different pathogenic organisms to heat varies significantly and questions have been raised about the use of the current indicator organisms. Most of the research done on pathogens in compost has examined Salmonella, E. coli, and total fecal coliforms. In addition, the compost examined is, most generally, made from manure and farm waste or municipal solid waste. In studies done by Mitsherlich and Marth 1984, Lung, et al. 2001, Turner 2002 and Hess, et al. 2004 , both Salmonella and E. coli were either inactivated or undetectable within 24 hours at temperatures greater than $50^{\circ} \mathrm{C}$, while fecal streptococcus and enterococcus took longer to show a reduction (Shuval, et al. 1991). These data show that Salmonella and E. coli are unlikely to survive in compost where temperatures exceed $50^{\circ} \mathrm{C}$ over a period of several days to two weeks. They also show that fecal streptococcus and enterococcus may be more resistant to temperatures in compost than either Salmonella or E. coli.

Thermal destruction of the other pathogens expected to be found in deer has been extensively studied in foods (Roy, et al. 1981, Craven and Blankenship 1983, Mitscherlich and Marth 1984, Doyle and Schoeni 1984, Ahmed, et al. 1995, Junega, et al. 1995, Lihono, et al. 2003, Murphy, et al. 2004, Price and Tom 2005). Most of the pathogens found in road-killed deer appear to be fairly easily killed by temperatures above $60^{\circ} \mathrm{C}$, so in order to assess the effectiveness of destruction of pathogens due to composting, it was decided that hardier indicator organisms should be used.

Smith, et al. 2005 describes the heartiness of bacteria as the relative ability of the organism to survive environmental stress and/or treatment processes. A rating of three indicates that there is sufficient data to suggest that the organism is capable of surviving when exposed to various stressors, while a rating of one would indicate that the organism would not be expected to survive when exposed to stressors. Salmonella, E. coli and E. coli O157:H7, as well as Campylobacter spp, Yersinia spp., and Listeria spp., all have a heartiness rating of one. Leptospira spp. and Streptococcus (enterococci) are a two and Clostridium perfringens and Mycobacterium are a three. This study was conducted to determine the reduction of pathogens in each category (1 through 3 ) as an indicator that all pathogens of concern in road-killed deer could be destroyed during composting. From heartiness level one, fecal coliforms, E. coli and Salmonella were chosen and fecal streptococcus and enterococcus from level two. Mycobacterium avium subspecies paratuberculosis (MAP) was chosen as the level three bacteria.

\section{Materials and Methods}

This project investigated the potential of composting as an option for managing road-killed animals. Research and demonstration pilot piles containing deer carcasses enveloped in wood chips were constructed and monitored in several locations in New York State (NYS). Composite samples were taken periodically over the course of a year. Monitoring included temperatures, pathogens and typical compost parameters. More intensive research was also conducted using three replicated piles at the Cornell composting site in Ithaca, NY where sentinel bags containing pathogens were planted within the piles and recovered at intervals throughout the year. Additional samples were taken at other locations in NYS that had been composting roadkilled animals for over a year to assess pathogen content and compost parameters at actual composting sites.

Six road-killed deer carcass compost piles were set up in 4 different locations. Three pilot piles were set up across NYS to capture differing climatic conditions. The pilot piles were set up at NYSDOT facilities in Watertown, Cortland and Highland, NY, and the research piles were set up at Cornell University in Ithaca, NY. Table 1 shows the location of the sites and the climatic conditions at each. 
TABLE 1.

Pile locations and climatic conditions

\begin{tabular}{|c|c|c|c|c|c|c|c|c|}
\hline \multirow[b]{2}{*}{ Location } & \multirow[b]{2}{*}{ Latitude } & \multirow[b]{2}{*}{ Longitude } & \multicolumn{2}{|c|}{ Average Temperature $\left({ }^{\circ} \mathrm{C}\right)$} & \multirow[b]{2}{*}{ December } & \multicolumn{2}{|c|}{ Average Snowfall (inches) } & \multirow{2}{*}{$\overline{\text { March }}$} \\
\hline & & & Summer & Winter & & January & February & \\
\hline Watertown & $43.98 \mathrm{~N}$ & $75.91 \mathrm{~W}$ & 21 & -7 & 29 & 34 & 23 & 15 \\
\hline Cortland & $42.59 \mathrm{~N}$ & $76.22 \mathrm{~W}$ & 21 & -7 & 23 & 23 & 19 & 15 \\
\hline Highland & $41.72 \mathrm{~N}$ & $73.96 \mathrm{~W}$ & 21 & -1 & 6 & 9 & 9 & 6 \\
\hline Ithaca & $42.15 \mathrm{~N}$ & $79.25 \mathrm{~W}$ & 24 & -1 & 15 & 17 & 15 & 10 \\
\hline
\end{tabular}

All of the piles were constructed in a similar manner. Approximately 24 inches of "clean" wood chips were laid down and two deer were placed on top. This layer was covered with approximately 18 inches of chips. Two more deer were laid down. Approximately two feet of wood chips were used to cover the piles. As the piles were being built, a sample of wood chips was taken to reflect pathogen content of the "compost" at time zero.

The wood chips used for the pilot piles were wood chips that had been stockpiled by each of the facilities. The deer in these piles were road-killed deer collected either over the weekend (at Watertown, thus the deer were cold) or that morning (at Cortland and Highland) and saved on site until the pile was built. The ambient temperature was approximately $14^{\circ} \mathrm{C}$ on Oct 31, 2005 when the Watertown and Cortland piles were built and on Nov 1, 2005 when the Highland pile was built. At the time the piles were built, Hobo U12 4Channel Outdoor/Industrial data loggers with $6 \mathrm{ft}$ temperature sensors (probes) were set up to record temperatures in the pile every half hour. Three temperature probes from these loggers were placed in the piles for the duration of the study (two probes in the bottom layer of the pile - one underneath one of the deer and the other between the deer - and one probe in the top layer of the pile between the deer). The $4^{\text {th }}$ probe was left outside the pile to record ambient temperature. However, as some probes were left in direct sunlight, temperatures recorded do not necessarily reflect the air temperature.

These 3 piles were truly static piles, that is, they were never turned and were disturbed only to sample. Compost was sampled at months 3, 6, 9 and 12. Three samples were taken from each pile. Three holes were dug around the perimeter of each of the piles. The first sample was a composite of compost taken from the ceiling of each of the holes at a depth of approximately $12^{\prime \prime}$. The second sample was a composite of compost taken from the ceiling of each of the holes at a depth of approximately 18 " and the third was taken at approximately 24 " into the pile.

The research piles (three replicated piles set up at Cornell University in Ithaca, NY) were constructed in the same manner as the pilot piles, except that the deer used in these piles had been collected over a one week period prior to pile construction on 11/8/05 and had been stored at $4.4^{\circ} \mathrm{C}$ for that week. In addition, the deer were split open and the spiral colon and blind sac were removed from each of them to create "deer goo" that was placed in nylon mesh bags and whiffle balls used to seed the abdominal cavities of each of the deer being placed in the piles. A second set of whiffle balls containing Johnes (Mycobacterium avium paratuberculosis $\mathrm{MAP}$ ) contaminated manure (obtained from the Cornell College of Veterinary Medicine) in nylon mesh bags were also inserted into the research pile carcasses (Figure 1). The wood chips used for these piles came from Tompkins County Department of Transportation. The month 0 compost sample was a single sample of wood chips that were used to build each of the 3 piles. At months 3, 6, 9, 12 and 18, three samples were taken from each pile as described for the pilot sites.

Deer goo was sampled at weeks $0,3,6,9,17$ and 36 . At week 0, 5 samples were taken at random from the 50 bags that were prepared for seeding into the deer carcasses. The remaining 45 bags were placed in whiffle balls and 15 were distributed in the 4 carcasses in each pile. At weeks 3, 6, 9, 17 and 36, three whiffle balls with deer goo were pulled from each of the three piles at the research site. Retrieving the whiffle balls required greater disturbance of the piles (digging in to find the balls) than taking compost samples. At week 36 (the week after month 9 compost samples had been taken), we had a hard time finding all of the remaining whiffle balls and used a backhoe in piles 1 and 2 to find them, essentially spreading out and reforming the piles. Therefore, piles 1 and 2 had been pulled apart prior to taking the month 12 compost samples. The backhoe was not used in pile 3, but the pile was extensively disturbed with a shovel. The backhoe was not cleaned prior to use and it is not known to what materials the bucket had been exposed. Due to the disturbance, the research piles were not truly static piles.

The compost samples and the "deer goo" were sent to Woods End Laboratories (WEL) for analysis of fecal coliforms, Escherichia coli, fecal streptococci, enterococci and Salmonella spp. All samples were received 


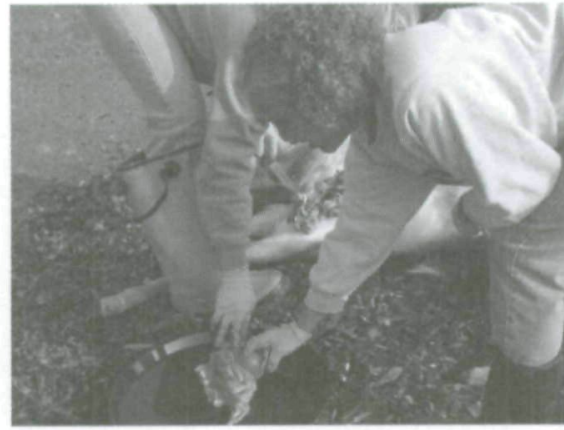

Cutting out spiral colon and blind sac

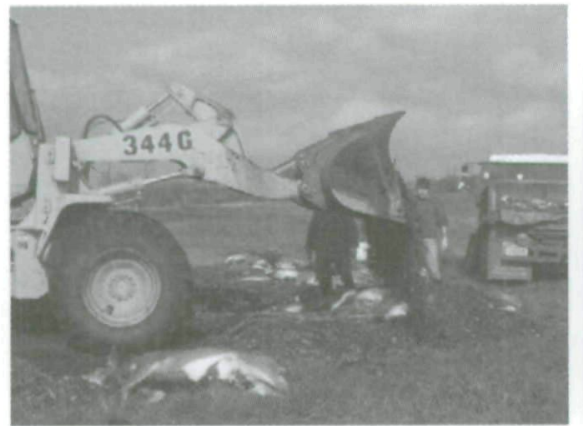

Covering 1st layer of deer with chips

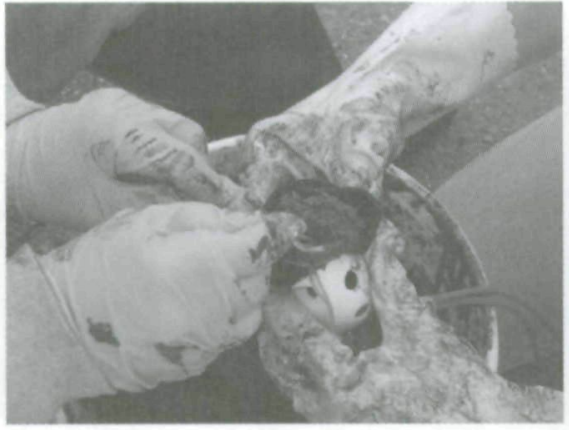

Filling bags and balls with MAP manure

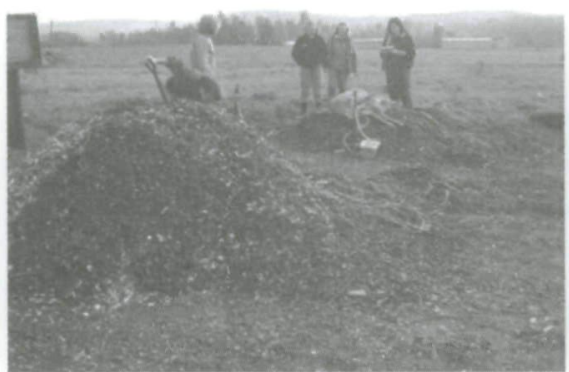

Foreground: finished pile; Background: 2nd layer

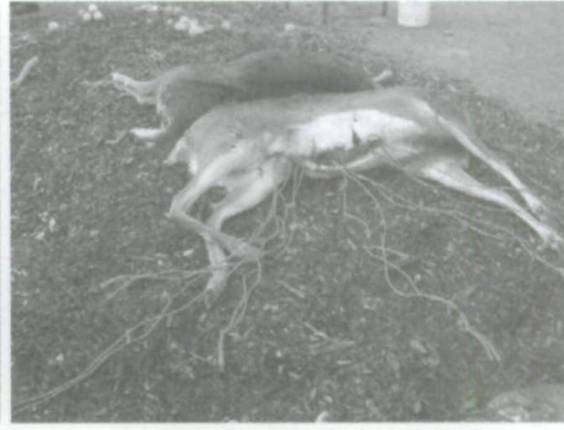

1st layer of deer seeded with balls

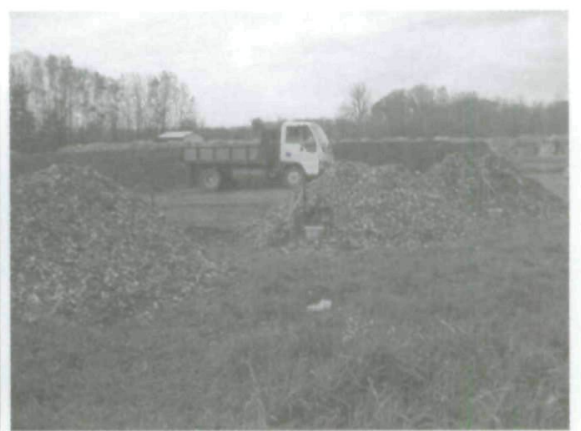

3 finished research piles

FIGURE 1. Building the research piles at Cornell University

double-bagged and labeled, and were shipped with cold-packs in an insulated cooler via air-express to arrive within $24 \mathrm{~h}$ at the laboratory. Compost samples were sent in plastic re-closable bags. For deer goo, at week 0 , the 5 samples that were sent for analysis went directly into a plastic re-closable bag, rather than in the nylon mesh bags being used for seeding. At all other weeks, the entire nylon mesh bag was put into a plastic re-closable bag. At week 3, the deer goo was removed from the nylon mesh bag at WEL prior to running the analysis procedure. At all other weeks, the deer goo remained in the nylon mesh bag and was put through a stomacher and prepared for analysis. Preparation of the samples for microbiological enumeration happened on the day of arrival in the lab.

General Sample Preparation: Aseptic conditions were maintained. For all the bacteria the process began with $30 \mathrm{~g}$ well mixed sample added to $270 \mathrm{ml}$ PBW (Phosphate Buffered Water) (American Public Health Association 1995), stomached (Seward 400 Stomacher) for $90 \mathrm{sec}$. at $200 \mathrm{rpm}$ in strainer stomacher bags (Seward) and diluted $11 \mathrm{ml}$ into $99 \mathrm{ml}$ PBW to prepare all other dilutions. All methods reported MPN/g Total Solids (per 4 grams for Salmonella). Total solids were determined by drying samples at $105^{\circ} \mathrm{C}$ for $24 \mathrm{hrs}$. Sterilization was by autoclave (Tuttnauer/Brinkmann $2540 \mathrm{M}$ ), and incubators included a waterbath (Precision Coliform model 253) and 3 Precision incubators (Models 5EM and 4EM).
Fecal coliform bacteria and generic Escherichia coli were enumerated by EPA Method 1680 (EPA 1999) modified to include generic E. coli. This is an elaborated Standard Methods 9221E+F (American Public Health Association 1995), a five tube MPN starting with inoculation of $1 \mathrm{~g}$ sample $(10 \mathrm{ml}$ of 0.1 dilution) in each of 5 tubes of 2X Lauryl Tryptose Broth [LTB Difco]). All other rows contain 5 tubes of 1 X LTB and serial dilutions of sample to $10^{-11}$ in order to achieve clear extinction. LTB incubated $24 \mathrm{~h}$ (and then $24 \mathrm{~h}$ more if not positive) at 35.5C. From each presumptive positive tube 10ul was inoculated into separate EC+MUG Broth (Difco) tubes. After $24 \mathrm{~h}$ at $44.5 \mathrm{C}$, tubes with gas were assumed fecal coliform positive and those that were fluorescent when exposed to $366 \mathrm{~nm}$ light were assumed to contain generic E. coli. Positive and negative controls were set throughout but no spiking of samples was done. $\mathrm{MPN} / \mathrm{g}$ was calculated using tables provided by EPA 1680 and FDA BAM (USFDA/CFSAN 2002).

Salmonella spp. were enumerated by EPA Method 1682 (EPA 1998). Enrichment of 20ml of the stomached sample (see above) in each of 5 tubes of $10 \mathrm{ml} 3 X$ TSB (Tryptic Soy Broth, Difco), $10 \mathrm{ml}$ in each of 5 tubes of 5 $\mathrm{ml}$ of $3 X$ TSB and $1 \mathrm{ml}$ of the stomached sample in each of 5 tubes of $10 \mathrm{ml}$ of 1 X TSB for $24 \mathrm{hr}$ at 37C; Modified Semisolid Rappaport Vassiliadis Agar (MSRV Difco) plates were inoculated with the TSB cultures the following day (one tube per plate, six $30 \mathrm{uL}$ drops from that tube distributed on the plate) and incubated 16- 
$18 \mathrm{~h}$ at $42 \mathrm{C}$. Two presumptive colonies from each plate were streaked to XLD plates and incubated $24 \mathrm{~h}$ at $37 \mathrm{C}$. Presumptive colonies ( 1 per XLD plate) were inoculated to TSI (Triple Sugar Iron agar), LIA (Lysine Iron Agar), Urea Agar, and (Tryptic Soy Agar with 5\% Sheep Blood) BAP and after $24 \mathrm{~h}$ at $37 \mathrm{C}$ the properties of the tubes and BAP were checked against those known for Salmonella, those of the positive control and all still presumptive tested with Poly-O Antiserum for Salmonella (Difco). MPN/4g was calculated using tables provided by EPA 1682 for solid samples. All agar tubes and plates were purchased from Northeast Laboratory Services (NEL, Winslow, ME).

Fecal Streptococci: SM 9230B (American Public Health Association 1995) protocol was followed to enumerate the fecal streptococci. A five-tube serial dilution $\left(10^{-1}-10^{-11}\right)$ MPN was set from the original sample dilution in tubes of Azide Dextrose Broth (Difco). After $48 \mathrm{~h}$ at $36 \mathrm{C}$ any turbid tube was struck to a Bile Esculin Azide agar plate (Remel) and incubated $48 \mathrm{~h}$ at $36 \mathrm{C}$. Any plates containing grey colonies that blacken the agar were assumed to be fecal streptococci. Confirmation of one typical colony from each Bile Esculin Azide Agar Plate in Brain-Heart Infusion Broth with $6.5 \% \mathrm{NaCl}$ (NEL Salt Tolerance Broth) at 46C 24h determined the Enterococcus MPN.

Positive control organisms included E. coli ATCC 25922, Enterobacter aerogenes ATCC 13048, Pseudomonas aeruginosa ATCC 27853, Salmonella typhimurium ATCC 14028, Enterococcus faecalis ATCC 29212 (Source: Microbiologics, Inc.).

MAP was sampled at weeks $0,3,6,9,12$ and 36 . At week 0,9 samples were taken at random while preparing the 54 bags for seeding into the deer carcasses. At weeks 3, 6, 9, 12 and 36, three whiffle balls with MAP were pulled from each of the 3 research piles. At week 36 , only 2 balls were found for MAP analysis in pile 3 . MAP samples were removed from the nylon mesh bag and placed in special containers provided by the New York State Animal Health Diagnostic Center at Cornell University, where they were sent for analysis. The procedure used was Cornell Double Incubation Decontamination for $M$. paratuberculosis culture from feces.

Day 1: First Decontamination and Incubation: Two grams of feces were weighed out into $35 \mathrm{ml}$ distilled water in a $50 \mathrm{ml}$ plastic centrifuge tube. The tube was shaken and sat at room temperature for $30 \mathrm{~min}-$ utes. A $5 \mathrm{ml}$ sample was taken with a pipet from the top portion of the tube and put in $25 \mathrm{ml}$ of $0.9 \%$ Hexadecylpyridinium chloride monohydrate (HPC) in П X Brain Heart Infusion (BHI) broth solution in a $50 \mathrm{ml}$ plastic centrifuge tube. The HPC is a detergent used to get rid of bacteria and fungus and the $\mathrm{BHI}$ is a nutrient used to grow the MAP. The tube was incubated for 18-
24 hours (overnight) at $35-37^{\circ} \mathrm{C}$.

Day 2: Second Decontamination and Incubation: The tube was centrifuged for 20 minutes at $3000 \mathrm{xg}$ at $15^{\circ} \mathrm{C}$. The supernatant was discarded and the pellet re-suspended by adding $1 \mathrm{ml}$ of antibiotic brew made of BHI plus 100, 100, 50 rg NVA (Nalidixic acid, Vanco, Amphatericin B). The tube was incubated overnight at $35-37^{\circ} \mathrm{C}$.

Day 3: Set up for Herrold's Egg Yolk Media (HEY): $0.2 \mathrm{ml}$ was dispensed from the centrifuge tube using a Liquipette onto 3 HEY tubes with Mycobactin J (MJ, a growth media needed for Johnes) and 1 HEY without MJ for comparison. Since MAP will not grow without MJ, if growth appears on all four tubes, it is not MAP. Tubes were set on a slant for 2 weeks to allow the liquid to dry then stood upright for 10 weeks. Tubes were read every week beginning at about 4 weeks by counting colonies, with a final count taken at 12 weeks.

\section{Results and Discussion}

\section{Temperature}

Even though the piles were started at the end of October and early November and the deer were cold, all piles heated up. Average daily temperatures varied within the piles (depending on location of the probe) and among sites. Temperatures appeared to be higher in the top layer of the pile. All probes in all piles reached $40^{\circ} \mathrm{C}$, the recommended temperature for pathogen reduction for Class $\mathrm{B}$ use.

Figure 2 shows the average daily temperatures recorded by the data logger in the Cortland, Highland and Watertown compost piles (pilot piles). The Cortland and Highland pile temperatures were what would be expected in a compost pile. There was an immediate increase in temperature reaching over $40^{\circ} \mathrm{C}$ within 2 days of building the pile, and remaining there between 9 and 75 days depending on the location of the probe despite the cold ambient temperatures. Watertown recorded temperatures, however, did not reflect those of a typical compost pile. Only one of the probes showed an increase in temperature early on, taking 12 days to reach $40^{\circ} \mathrm{C}$, while the other two remained below about $20^{\circ} \mathrm{C}$ for 6 months. This may reflect the fact that the deer were very cold when placed in the pile. In April, all three probes showed an increase in temperature, but the high temperature reached was only around $50^{\circ} \mathrm{C}$. The climate in Watertown through the winter includes high winds and little snow. Deer and chips may have been too cold to increase in temperature under those conditions. In climates with frequent wind, a more dense carbon source may be required. 
Average Daily Temperature in the Cortland Compost Pile

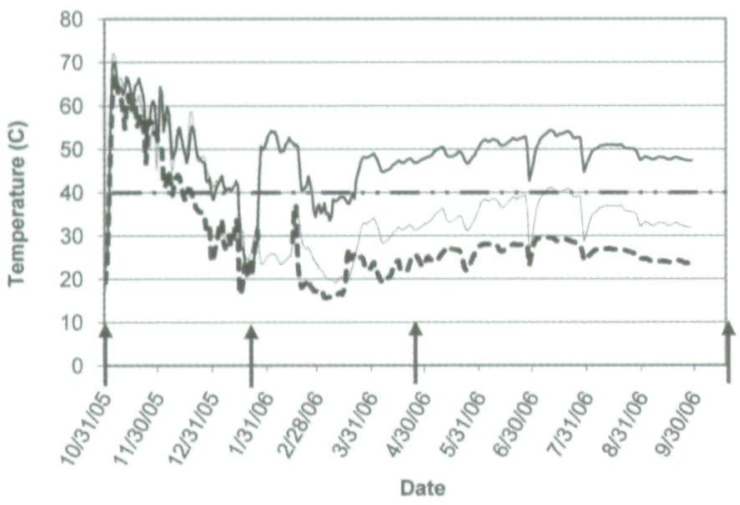

Average Daily Temperature in the Highland Compost Pile

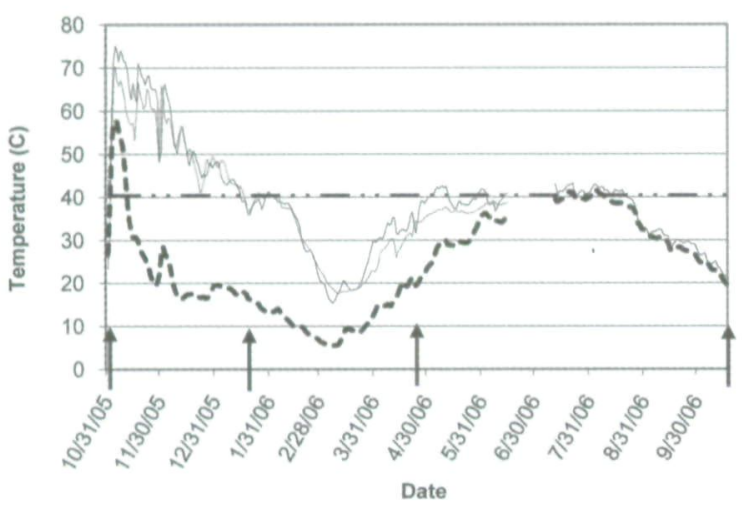

Average Daily Temperature in the Watertown Compost Pile

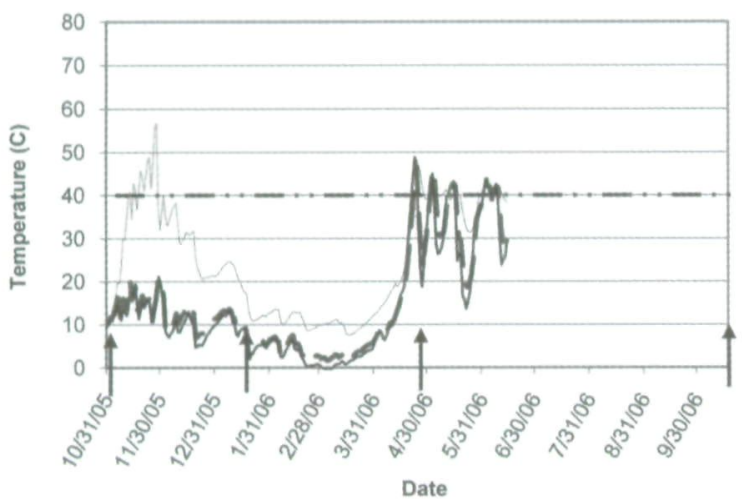

Bottom - - -

Bottom - . - . -

Top -
$40 \mathrm{c}-\cdots-$

Sampling $\uparrow$

FIGURE 2. Average daily temperatures in the three pilot compost piles over time at Cortland, Highland and Watertown, NY

\section{Compost Pathogens}

The organisms that the USEPA requires for evaluation of the hygienic quality of sewage sludges are Salmonella and fecal coliforms. One standard for fecal coliforms in sewage sludge deemed by USEPA to be
Class A, suitable for unrestricted use, is $1000 \mathrm{MPN}$ ( 3 $\log _{10}$ ). For sludges used where public contact is limited, the Class B standard is 2 million MPN/g $\left(6.3 \log _{10}\right)$ for fecal coliforms.

Statistical analysis of pathogen levels in the composts was done using the S-Plus statistical package. Differences in pathogen levels at each sampling were analyzed for the three pilot piles together, and the three research piles together using analysis of variance (ANOVA) for multiple comparisons with Tukey corrections. Pathogen concentrations were high in the woodchips used in constructing the pilot piles before any deer carcasses were buried (fecal coliforms started at $4.49 \log _{1,}$ lower than Class B, but higher than class A). Regardless of the temperatures in the piles, at the pilot sites where pathogen levels in woodchips only were high in the beginning, it took 3-6 months to see a significant decrease in pathogen numbers. Table 2 shows the average level of pathogens analyzed in $\log _{10}$ MPN/g solids for the three pilot piles. Fecal coliform and $E$. coli levels were reduced significantly by month 6 in the compost at the pilot sites. There was a $1 \log _{10}$ reduction in fecal coliform numbers and a $1.5 \log _{10}$ reduction in E. coli. By month 9, levels of both fecal coliforms and E. coli had reduced from 30,000 and 3,000 respectively to 10 and $3 \mathrm{MPN} / \mathrm{g}$ solids. Fecal streptococci and enterococci were significantly reduced in the compost at the pilot sites by month 3 ( $2 \log _{10}$ reduction) and then again at month 12 reducing numbers from 23 million fecal streptococci and 56 thousand enterococci to 400 and 6 respectively. Since fecal streptococci and enterococci are more resistant to heat than fecal coliforms and $E$. coli, this faster reduction of numbers may come from the athermic properties of composting, rather than temperature alone.

TABLE 2 .

Average pathogen levels in compost over time at the pilot sites ( $\log _{10} \mathrm{MPN} / \mathrm{g}$ solids)

\begin{tabular}{lccccc}
\hline Pathogen & Month 0 & Month 3 & Month 6 & Month 9 & Month 12 \\
\hline Fecal coliforms & $4.49^{\mathrm{a}}$ & $3.80^{\mathrm{ab}}$ & $3.48^{\mathrm{b}}$ & $1.00^{\mathrm{c}}$ & $0.22^{\mathrm{c}}$ \\
Escherichia coli & $3.57^{\mathrm{a}}$ & $2.81^{\mathrm{ab}}$ & $1.94^{\mathrm{b}}$ & $0.53^{\mathrm{c}}$ & $0.19^{\mathrm{c}}$ \\
Fecal streptococci & $7.37^{\mathrm{a}}$ & $5.00^{\mathrm{b}}$ & $4.24^{\mathrm{bc}}$ & $3.00^{\mathrm{c}}$ & $2.62^{\mathrm{c}}$ \\
Enterococci & $4.75^{\mathrm{a}}$ & $2.80^{\mathrm{b}}$ & $1.72^{\mathrm{bc}}$ & $2.20^{\mathrm{bc}}$ & $0.81^{\mathrm{c}}$
\end{tabular}

Mean values with differing superscripts in each row are significantly different $-\mathrm{p}<0.05$

At Cornell, where the woodchips had lower pathogen numbers (lower than Class A levels of fecal coliform), levels remained low through month 9 and then increased significantly at month 12 (Table 3 ). This was most likely from severe disturbance on the piles just after the month 9 sampling. Piles were deconstructed so that we could find the remaining samples 
TABLE 3.

Average pathogen levels in compost over time at the research site ( $\log _{10}$ MPN/g solids)

\begin{tabular}{lcccccc}
\hline Pathogen & Month 0 & Month 3 & Month 6 & Month 9 & Month 12 & Month 18 \\
\hline Fecal coliforms & $2.72^{\mathrm{a}}$ & $2.15^{\mathrm{a}}$ & $2.58^{\mathrm{a}}$ & $2.75^{\mathrm{a}}$ & $4.59^{\mathrm{b}}$ & $1.64^{\mathrm{a}}$ \\
Escherichia coli & $2.72^{\mathrm{a}}$ & $1.62^{\mathrm{a}}$ & $1.55^{\mathrm{a}}$ & $2.00^{\mathrm{a}}$ & $4.50^{\mathrm{b}}$ & $1.63^{\mathrm{a}}$ \\
Fecal streptococci & $5.20^{\mathrm{ab}}$ & $3.90^{\mathrm{bc}}$ & $3.66^{\mathrm{c}}$ & $3.27^{\mathrm{c}}$ & $5.31^{\mathrm{a}}$ & $2.87^{\mathrm{c}}$ \\
Enterococci & $2.59^{\mathrm{ab}}$ & $2.63^{\mathrm{a}}$ & $2.38^{\mathrm{ab}}$ & $1.64^{\mathrm{b}}$ & $4.10^{\mathrm{c}}$ & $2.10^{\mathrm{ab}}$
\end{tabular}

Mean values with differing superscripts in each row are significantly different $-p<0.05$

using a backhoe that had not been cleaned prior to use. The piles were left for another 6 months and a set of samples showed that at 18 months, pathogen levels were either back to previous levels $(<100 \mathrm{MPN} / \mathrm{g}$ solids for fecal coliforms, E. coli, and enterococci) and significantly reduced from 158,000 to $750 \mathrm{MPN} / \mathrm{g}$ solids for fecal streptococci.

\section{Sentinel Bags of Deer Intestinal Contents: Deer goo}

Statistical analysis of pathogen levels in the deer goo was done using the S-Plus statistical package. Differences in pathogen levels at each sampling were analyzed for the three research piles together using analysis of variance (ANOVA) for multiple comparisons with Tukey corrections (Table 4). Fecal coliform and Escherichia coli levels in the deer goo in the 3 research piles decreased significantly within 6 weeks of pile establishment. Reduction may have occurred earlier, but since the week 3 samples were handled differently in the lab they are not comparable to the other data and were not included in the analysis. A significant decrease of $7 \log _{10}$ after 6 weeks in the compost pile for fecal coliforms, and $9 \log _{10}$ reduction for E. coli was measured. Fecal streptococci and enterococci levels took longer to decrease. There was a $3 \log _{10}$ reduction by week 6 for fecal strep with an additional $3 \log _{10}$ reduction at week 36 . Enterococci levels remained the same until week 36 , when there was a $3 \log _{10}$ reduction.

Regression of pathogen levels over time were run for the three research piles together using the JMP statistical package. There was a rapid severe drop in fecal

TABLE 4 .

Average pathogen levels in deer goo over time at the research site $\left(\log _{10}\right.$ MPN/g solids)

\begin{tabular}{lccccc}
\hline Pathogen & Week 0 & Week 6 & Week 9 & Week 17 & Week 36 \\
\hline Fecal coliforms & $9.96^{\mathrm{a}}$ & $2.35^{\mathrm{b}}$ & $0.12^{\mathrm{b}}$ & $0.29^{\mathrm{b}}$ & $2.37^{\mathrm{b}}$ \\
Escherichia coli & $9.96^{\mathrm{a}}$ & $0.27^{\mathrm{bc}}$ & $-0.42^{\mathrm{c}}$ & $-0.14^{\mathrm{c}}$ & $1.31^{\mathrm{b}}$ \\
Fecal streptococci & $8.18^{\mathrm{a}}$ & $5.83^{\mathrm{b}}$ & $5.08^{\mathrm{b}}$ & $5.27^{\mathrm{b}}$ & $2.43^{\mathrm{c}}$ \\
Enterococci & $5.42^{\mathrm{a}}$ & $5.03^{\mathrm{a}}$ & $4.63^{\mathrm{a}}$ & $3.74^{\mathrm{ab}}$ & $2.10^{\mathrm{b}}$
\end{tabular}

Mean values with differing superscripts in each row are significantly different $-\mathrm{p}<0.05$ coliform and E. coli levels in the deer goo. Non-linear regression of the fecal coliform levels in deer goo showed an exponential rate of decay of $0.28\left(\mathrm{e}^{0.28}=1.3\right.$ or $30 \%$ decrease per week), with a half-life of 2.45 weeks and an exponential rate of decay of $0.67\left(\mathrm{e}^{0.67}=1.95\right.$ or $95 \%$ decrease per week) for $E$. coli, with a half life of 1.03 weeks (Figure 3). It took less than 6 weeks to reduce pathogen numbers below the "benchmark" level of $6.3 \log _{10}$ MPN/g solids of fecal coliforms deemed necessary for USEPA Class B use.
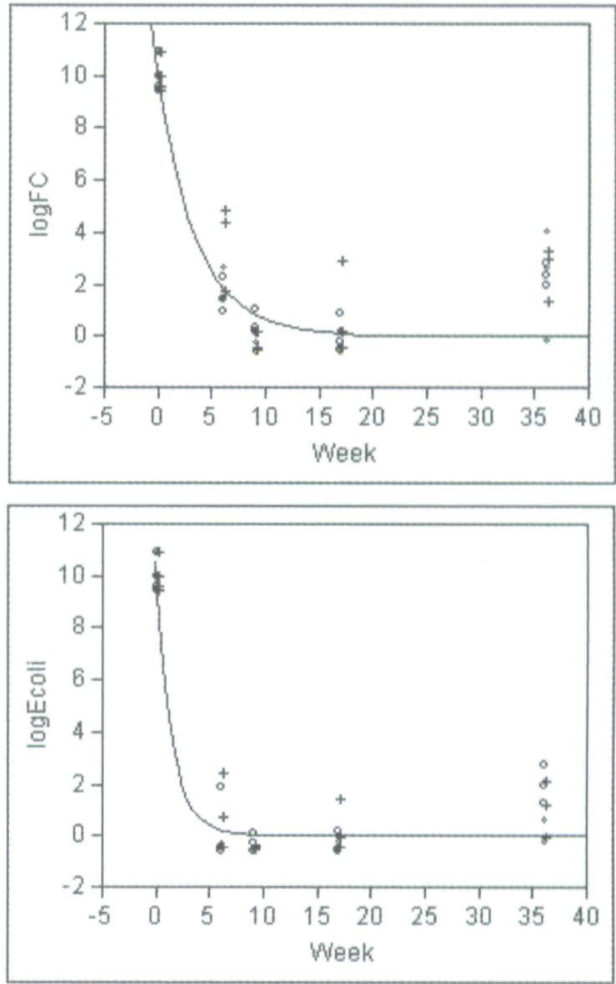

FIGURE 3. Exponential decay of fecal coliforms (top) and E. coli (bottom) in deer goo over time in the research piles.

Fecal streptococcus and enterococci levels decreased more slowly and linearly than did fecal coliforms and E. coli. Linear regression of fecal streptococcus levels in the deer goo showed a significant decrease of $0.146 \mathrm{MPN} / \mathrm{g} /$ week with an $\mathrm{r}^{2}$ value of 0.651 , and enterococci levels in the deer goo showed 
a significant decrease of $0.091 \mathrm{MPN} / \mathrm{g} /$ week with an $r^{2}$ value of 0.529 (Figure 4). Although there is no benchmark value for fecal streptococci and enterococci, it took 36 weeks ( 9 months) for fecal streptococci and enterococci to decrease below $6.3 \log _{10}$ $\mathrm{MPN} / \mathrm{g}$ solids in the deer goo.
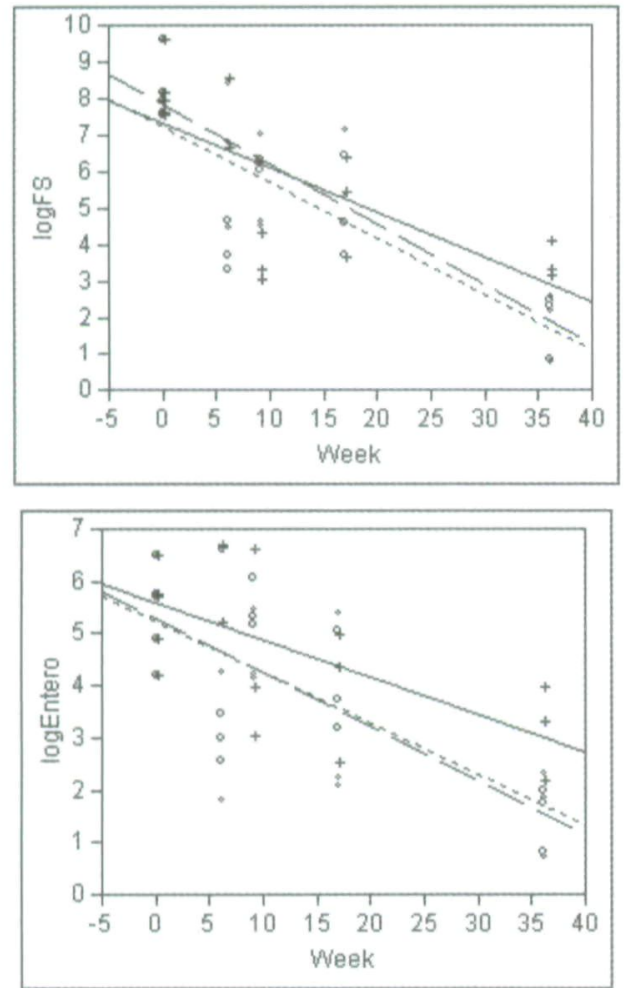

FIGURE 4. Linear decay of fecal streptococcus (top) and enterococci (bottom) in deer goo over time in the research piles.

\section{Mycobacterium avium paratuberculosis (MAP)}

While not generally considered an important disease in wild deer, MAP (the bacteria that causes
Johne's disease in cattle) was selected as an indicator organism because it is relatively hardy, surviving higher temperatures than fecal coliform, and does not reproduce in the environment. MAP contaminated manure was placed in sentinel bags in the deer carcasses in the research piles. Differences in pathogen levels at each sampling were analyzed for the three research piles together using analysis of variance (ANOVA) for multiple comparisons with Tukey corrections using the S-Plus statistical package.

MAP levels decreased significantly to near 0 (from $4.51 \log _{10} \mathrm{cfu} / \mathrm{g}$ to $0.19 \log _{10} \mathrm{cfu} / \mathrm{g}$ ) within 3 weeks, and remained at those levels until week 36 (Table 5). At week 36, several of the samples had values around $2 \log _{10} \mathrm{cfu} / \mathrm{g}$, which would be considered "few" for dairy cattle, posing a slight risk for the spread of Johne's disease to other cattle. One of the samples contained "many" or too numerous to count. It is not clear why these samples had these levels of MAP since this organism is not thought to be able to reproduce outside of a host and previously measured levels were low. This may have occurred because MAP tend to clump and can be hard to find therefore some of the clumps of organism may not have been exposed to high enough temperatures or were not detected in previous sample testing.

\section{Compost Parameters}

The compost samples taken at months 3, 6,9 and 12 were sent to Woods End Laboratory in Maine for analysis. When the samples arrived at the laboratory, they were screened to less than $3 / 8^{\prime \prime}(10 \mathrm{~mm})$. This portion of the sample was then ground and analyzed for compost quality parameters. The following information shows the combined analysis from all piles together for particle size, carbon:nitrogen ratio $(\mathrm{C}: \mathrm{N})$, total nitrogen $(\mathrm{TN})$, phosphorus $(\mathrm{P})$ and

TABLE 5.

MAP $\left(\log _{10} \mathrm{cfu} / \mathrm{g}\right.$ wet weight) in manure over time (nine samples taken each week)

\begin{tabular}{|c|c|c|c|c|c|c|}
\hline & Week 0 & Week 3 & Week 6 & Week 9 & Week 17 & Week 36 \\
\hline & 4.58 & 0.00 & 0.00 & 0.00 & 0.00 & 2.11 \\
\hline & 4.58 & 0.00 & 0.00 & 0.00 & 0.00 & 1.88 \\
\hline & 4.65 & 0.00 & 0.00 & 0.88 & 0.88 & No sample \\
\hline & 4.35 & 1.72 & 0.00 & 0.00 & 0.00 & 2.29 \\
\hline & 4.49 & 0.00 & 1.18 & 0.00 & 0.00 & 1.72 \\
\hline & 4.42 & 0.00 & 0.00 & 0.88 & 0.00 & 0.00 \\
\hline & 4.62 & 0.00 & 0.00 & 0.00 & 0.00 & 1.88 \\
\hline & 4.34 & 0.00 & 0.00 & 0.00 & 0.00 & 3.35 \\
\hline & 4.60 & 0.00 & 0.00 & 0.00 & 0.00 & 2.18 \\
\hline Mean & $4.51^{\mathrm{a}}$ & $0.19^{b}$ & $0.13^{b}$ & $0.19^{b}$ & $0.10^{b}$ & $1.92^{c}$ \\
\hline
\end{tabular}

Mean values with differing superscripts are significantly different $-p<0.05$ 
TABLE 6.

Mean values for compost quality parameters of road-killed compost over time

\begin{tabular}{lcccc}
\hline Parameter & Month 3 & Month 6 & Month 9 & Month 12 \\
\hline Percent particles $<3 / 8^{\prime \prime}$ & $61.6^{\mathrm{a}}$ & $51.6^{\mathrm{a}}$ & $59.8^{\mathrm{a}}$ & $56.8^{\mathrm{a}}$ \\
Carbon:nitrogen ratio & $71.2^{\mathrm{a}}$ & $62.1^{\mathrm{a}}$ & $35.8^{\mathrm{b}}$ & $34.5^{\mathrm{b}}$ \\
Total nitrogen & $0.65^{\mathrm{a}}$ & $0.81^{\mathrm{ab}}$ & $1.37^{\mathrm{bc}}$ & $1.50^{\mathrm{c}}$ \\
Total phosphorus & $0.07^{\mathrm{a}}$ & $0.08^{\mathrm{a}}$ & $0.11^{\mathrm{a}}$ & $0.24^{\mathrm{b}}$ \\
Solvita ${ }^{\circledR}$ maturity & $3.8^{\mathrm{a}}$ & $5.3^{\mathrm{ab}}$ & $4.0^{\mathrm{a}}$ & $6.9^{\mathrm{b}}$ \\
\hline
\end{tabular}

Mean values with differing superscripts in each row are significantly different $-\mathrm{p}<0.05$

Solvita ${ }^{\circledR}$ maturity. Statistical analysis was done by ANOVA and linear regression using JMP. Table 6 shows the mean values for each of these parameters over time.

The percent of particles in the compost that measured less than $3 / 8^{\prime \prime}$ remained constant over time. The C:N ratio started high (71.2) and decreased significantly over time indicating that composting was occurring and that the nitrogen from the carcasses was mixing with the carbon from the wood chips. As composting progressed, the C:N ratio decreased until month 9 when it was at levels considered appropriate for initiating a compost process. The final material is thus not a "finished compost" and would be best used as a carbon source for other piles, though it was successfully used as is to seed a roadside bank. Nitrogen levels increased significantly over time in both the pilot and research piles. The average value of $1.5 \%$ at month 12 is within the range typical for composts. Phosphorus levels increased significantly over the project period, although there was no statistical difference until month 12 . The average value of $0.224 \%$ at month 12 is within the range typical for composts. Maturity was calculated using the Solvita ${ }^{\circledR}$ maturity test. This procedure measures the evolution of carbon-dioxide $\left(\mathrm{CO}_{2}\right)$ and emission of ammonia $\left(\mathrm{NH}_{3}\right)$, two important factors for determining stability and maturity. The results are recorded as a maturity index ranging from 1 ("raw" compost) to 8 ("finished" compost). Solvita 6 and above is commonly recognized as suitable maturity for official uses. The maturity of the compost was generally low until month 12. Maturity increased significantly over time in both the pilot and Cornell piles averaging 6.9 in month 12 .

\section{Conclusions}

Composting of deer carcasses was effective in reducing pathogen levels, decomposing the carcasses and producing a useable end product after 12 months. Temperatures in the piles, regardless of the cold ambient temperature, reached over $40^{\circ} \mathrm{C}$ within 2 weeks of building the piles, allowing for the decomposition process of the carcasses to start. Pathogen levels were reduced to near zero levels in all of the piles and within the deer carcasses and thus can be used for highway department projects.

\section{Acknowledgements}

The authors gratefully acknowledge the help of New York State Department of Transportation (NYSDOT), New York State Department of Environmental Conservation, Woods End Laboratories, New York State College of Veterinary Medicine, New York State College of Industrial and Labor Relations, and other cooperators. Funding for this project was provided by the NYSDOT, Cornell Cooperative Extension and the College of Agriculture and Life Sciences at Cornell University.

\section{References}

Ahmed, N.M., D.E. Conner and D.L. Huffman. (1995) Heatresistance of Escherichia coli O157:H7 in meat and poultry as affected by product composition. Journal of Food Science, 60(3):606-610.

American Public Health Association. (1995) Standard methods for the examination of water and wastewater $19^{\text {th }}$ Ed., Washington, D.C.

Branham, L.A., M.A. Carr, C.B. Scott, and T.R. Callaway. (2005) E. coli O157 and Salmonella spp. in white-tailed deer and livestock. Current Issues in Intestinal Microbiology 6:25-29.

Broda, D.M., R.G. Bell, J.A. Boerema, and D.R. Musgrave. (2002). The abattoir source of culturable psychrophilic Clostridium spp. causing 'blown pack' spoilage of vacuum-packed chilled venison. Journal of Applied Microbiology, 93:817-824.

Clifton-Hadley, R.S., C.M. Sauter-Louis, I.W. Lugton, R. Jackson, P.A. Durr, and J.W. Wilesmith. Mycobacterial diseases. Part II Chap. 21 In: Infectious Diseases of Wild Animals 3rd Edition. Eds. Elizabeth S. Williams and Ian K. Barker. Iowa State University Press, Ames, Iowa. 2001. P. 340-371.

Craven, S.E. and L.C. Blankenship. (1983) Increased heat resistance of Salmonellae in beef with added soy proteins. Journal of Food Protection, 46(5):380-384.

Doyle, M.P. and J.L. Schoeni. (1984) Survival and growth characteristics of Escherichia coli associated with hemorrhagic colitis. Applied and Environmental Microbiology, 48(4):855-856.

Fleming, W.J., and S.R. Nusbaum. (1979) A survey of deer on the Seneca Army Depot for evidence of leptospirosis, brucellosis and toxoplasmosis. New York Fish and Game Journal, 26(2):198.

Henderson, T.G. and P. Hemmingsen. (1983) Faecal survey of deer for Yersinia pseudotuberculosis and Salmonella sp. New Zealand Veterinary Journal, 31:225-226.

Henderson, T.G. (1984) The isolation of Yersinia sp. from feral and farmed deer faeces. New Zealand Veterinary Journal, 32(6):88-90.

Hess, T. F., I. Grdzelishvili, H. Sheng and C.J. Hovde. (2004) Heat inactivation of $E$. coli during manure composting. 
Compost Science and Utilization, 12(4):314-322.

Juneja, V.K., B.S. Marmer, J.G. Phillips, and A.J. Miller. (1995) Influence of the intrinsic properties of food on thermal inactivation of spores of nonproteolytic Clostridium botulinum: Development of a predictive model. Journal of Food Safety, 15(4):349-364.

Koronkiewicz, A. E. Daczkowska-Kozon, K. Markiewicz, A. Wojciechowska, E. Zmuda and W. Dabrowski. (2004) Game animals as carriers of enteric pathogens. Folia Universitatis Agriculturae Stetinensis, Scientia Alimentaria. 3:79-84.

Lihono, M.A., A.F. Mendonca, J.S. Dickson, P.M. Dixon (2003). A predictive model to determine the effects of temperature, sodium pyrophosphate, and sodium chloride on thermal inactivation of starved Listeria monocytogenes in pork slurry. Journal of Food Protection, 66(7):1216-1221.

Lillehaug, A., B. Bergsj, J. Schau, T. Bruheim, T. Vikren, K. Handeland. (2005) Campylobacter spp. Salmonella spp., verocytotoxic Escherichia coli, and antibiotic resistance in indicator organisms in wild cervids. Acta Veterinaria Scandinavica, 46(1/2):23-32.

Lung, A.J., C. M. Lin, J.M. Kim, M.R. Marshall, R. Nordstedt, N.P. Thompson and C.I. Wei. (2001). Destruction of Escherichia coli O157:H7 and Salmonella enteritidis in cow manure composting. Journal of Food Protection, 64(9):1309-1314.

Miller, M.W., E.S. Williams, N.T. Hobbs, L.L. Wolfe. (2004) Environmental sources of prion transmission in mule deer. Emerging Infectious Diseases [serial on the Internet]. Available from: http://www.cdc.gov/ncidod/ EID/vol10no6/04-0010.htm

Mitscherlich, E. and E.H. Marth. (1984) Microbial Survival in the Environment: Bacteria and Rickettsiae Important in Human and Animal Health. Springer-Verlag, Berlin.

Murphy, R.Y., B.L. Beard, E.M. Martin, L.K. Duncan and J.A. Marcy. (2004) Food Microbiology and Safety (FMS) Comparative Study of Thermal Inactivation of Escherichia coli O157:H7, Salmonella, and Listeria monocytogenes in Ground Pork. Journal of Food Science: an official publication of the Institute of Food Technologists, 69(4): FMS97.

O'Reilly, L.M., and C.J. Daborn. (1995) The epidemiology of Mycobacterium bovis infection in animals and man: a review. Tubercle and Lung Disease. 76 (Supplement 1), $1-46$.

Pagano, A., G. Nardi, C. Bonaccorso, V. Falbo, C. Passi, V.
Sanguinetti, and A. Mantovani. (1985) Faecal bacteria of wild ruminants and the alpine marmot. Veterinary Research Communications, 9:227-232.

Price, R. J. and P.D. Tom. Compendium of Fish and Fishery Product Processes, Hazards and Controls. National Seafood HACCP Alliance for Training and Education. Retrieved 9/12/05 from the University of California Seafood Information Network Web site. http:/ / seafood.ucdavis.edu/haccp/compendium/co mpend.htm

Rickard, L.G., C. Siefker, C.R. Boyle, E.J. Gentz. (1999) The prevalence of Cryptosporidium and Giardia spp. in fecal samples from free-ranging white-tailed deer (Odocoileus virginianus) in the southeastern United States. Journal of Veterinary Diagnostic Investigation, 11:65-72.

Roy, R.J., F.F. Busta, and D.R. Thompson. (1981) Thermal inactivation of Clostridium perfringens after growth at several constant and linearly rising temperatures. Journal of Food Science, 46:1586-1591.

Shayegani, M. W. Stone, I. Deforge, T. Root, L. Parsons and P.S. Maupin. (1986) Yersinia enterocolitica and related species isolated from wildlife in New York State. Applied and Environmental Microbiology, 52, (3):420-424.

Shotts, E.B., W.E. Greer, and F.A. Hayes. (1958) A preliminary survey of the incidence of Brucellosis and Leptospirosis among white-tailed deer (Odocoileus virginianus) of the Southeast. Journal of the American Veterinary Medical Association, 133(7):359-361.

Shuval, H., R. Jocide, M. Consiglio, G. Spagiarri, and C. Spigoni. (1991) Control of enteric microorganisms by aerobic thermophilic co-composting of waster water sludge and agro-industry wastes. Water Science and Technology, 24:401-405.

Smith, Jr., J.E., P.D. Milner, W. Jakubowski, N. Goldstein, and R. Rynk, eds. (2005) Contemporary Perspectives on Infectious Disease Agents in Sewage Sludge and Manure. The JG Press.

Turner, C. (2002) The thermal inactivation of E. coli in straw and pig manure. Bioresource Technology, 84:57-61.

United States Food and Drug Administration Center for Food Safety \& Applied Nutrition (USFDA/CFSAN). (2002) Chapter 4 In: Bacteriological Analytical Manual Online (BAM). Available at http://www.cfsan.fda.gov/ ebam/bam-4.html

USEPA (1998) Methods and guidance for the analysis of water, version 2 (includes EPA Series 500, 600, 1600 methods) (on CD-ROM). 
Copyright of Compost Science \& Utilization is the property of JG Press, Inc. and its content may not be copied or emailed to multiple sites or posted to a listserv without the copyright holder's express written permission. However, users may print, download, or email articles for individual use. 